p. 34

水中における鿓荷当時の血压变動

東京体声馆 铃 木 蔵 治

\section{I 席}

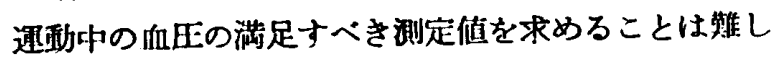
く，遇動の血正に対する影嫣を研究する人々の多くは，

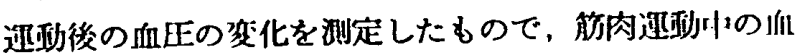
正を面接捉えたるのは少ない上らである.

速牥中の们王の测定器具には，あまり進少がみられな

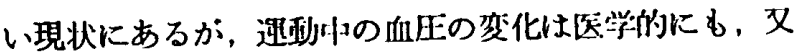
体奔科学の上からあ非学に舆味ある䦌超である.

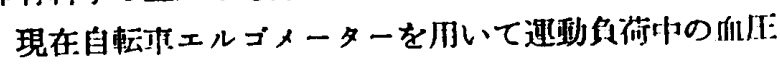
测定が考えられているが，同し梯な方法を田いて水けに

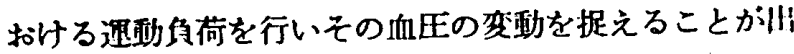
来たと思われるので報告する。

\section{II 実䛗方法}

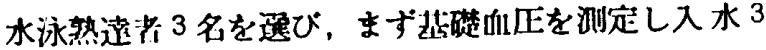
分问及び前後安都時の 血正（水温 $17^{\circ} \mathrm{C}, 21^{\circ} \mathrm{C}, 25^{\circ} \mathrm{C}$,

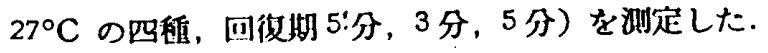
次いでこれを基礎资料として $21^{\circ} \mathrm{C}, 25^{\circ} \mathrm{C}, 27^{\circ} \mathrm{C}$ の水小

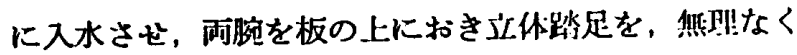

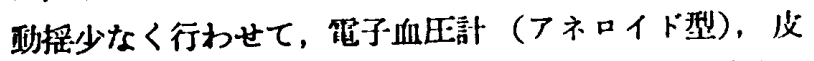

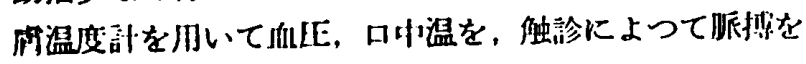
测定した。角街期 3 分，回微期 5 分とした。

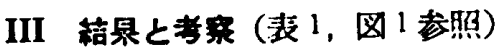

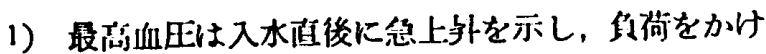

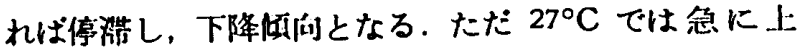
升するのも下降するのむある.いずれる眽塮数の娍少を

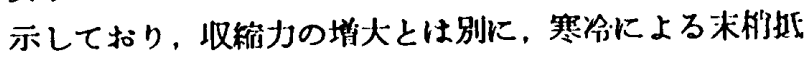

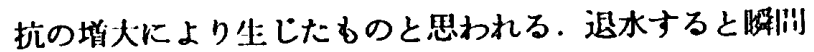
的に旧に後するよらに変怔するようである。

2) 最低血正は $17^{\circ} \mathrm{C}, 21^{\circ} \mathrm{C}$ は上多候问, $25^{\circ} \mathrm{C}$ では

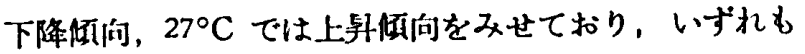
下るものも,上るものむある.これは，気温その他陸士

\section{表 1}

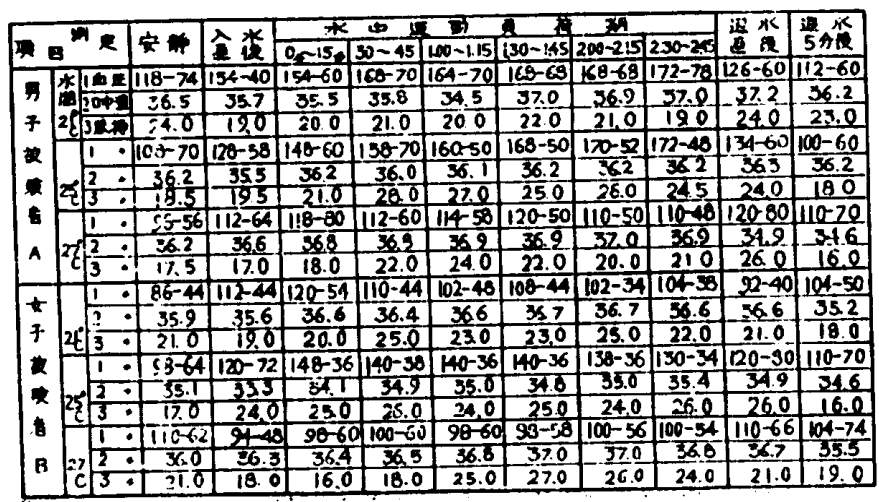

图 1

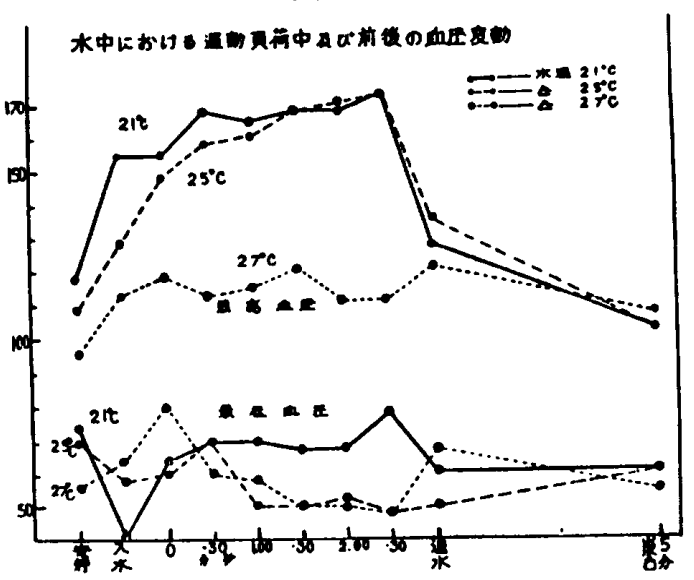

での策俳によつて安静時の血压值が放妙に変化している にも拘らず水温は一力的な寒冷刺战を饰えていることに よるものと思われる。この意味で其濋们压との测係にお いて阿考与る余地があると考えられる，1）と同様迟水 すると百ちに资汧する。

3）哌匹は被閄都によりまちまちで明らかではないが 入水活後から大となるようである。こ机は末相抵抗が活

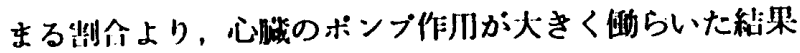

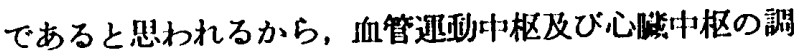
整们川が然泠に刘して防衡的に勘いていることによると 思われる。

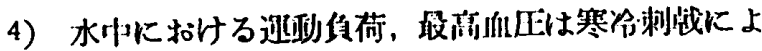
つて急上新を生し，そのままで入水が短時间であれば。

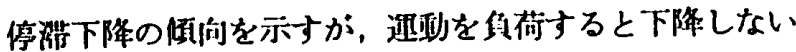

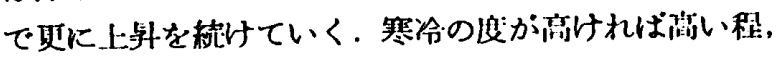

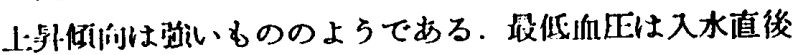

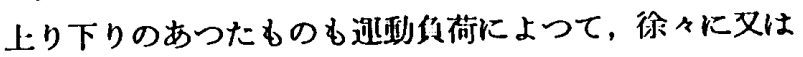
忽に下降を胃せ迎秒終了後まで下降的停湴を縝ける。 れに似た状腎は，そのまま份荷を少えない综でる起る か，この第合には迅秒による末梢血管の拨張によつて起 つたものと考える. 又その封最高血正が下降しないの は，最低仙正か下降してひ进政を続けて行つたためと思 れれる。

括

1）入水直後急上年した恨高向正は逃标によつて

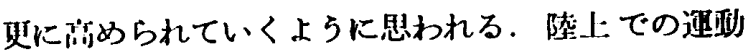
もこのような経過を巡るむのと考える。

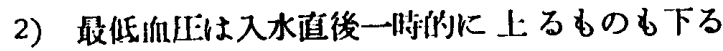

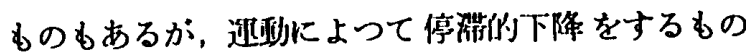
と思わ机る.

3）迎動を负荷しない場合です退水すると瞬時に 最离，最低近正に变化がみられる， 